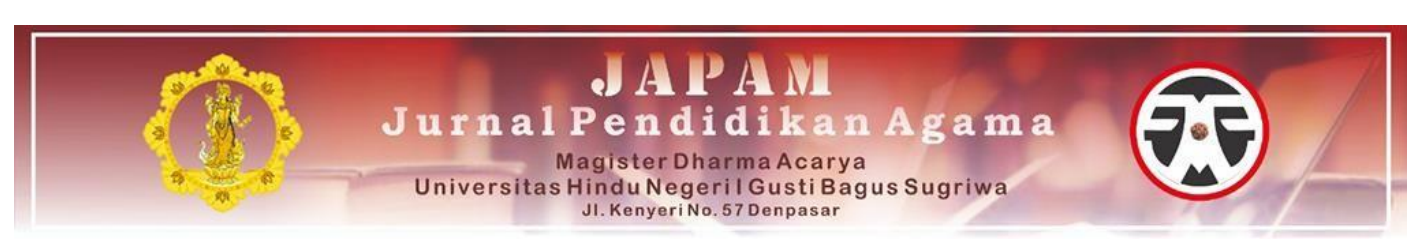

\title{
PENDIDIKAN KARAKTER DALAM MEMBANGUN MENTALITAS DISIPLIN ANAK DIDIK
}

\author{
Oleh: \\ I Nyoman Temon Astawa ${ }^{1}$, Ni Wayan Sukerti ${ }^{2}$ \\ ${ }^{1}$ Universitas Hindu Negeri I Gusti Bagus Sugriwa Denpasar, ${ }^{2}$ SDN 1 Batubulan \\ e-mail: ${ }^{\text {temonastawa@gmail.com }}$ \\ Diterima: 25 Agustus 2021, Direvisi: 08 September 2021, Diterbitkan: 18 Oktober 2021
}

\begin{abstract}
Abstrak
Pendidikan merupakan proses memanusiakan manusia yaitu suatu proses yang maтрu mewujudkan manusia seutuhnya, melakukan penyadaran untuk mengenal, mengerti, dan memahami realitas kehidupan yang ada di sekelilingnya. Menurut Undang-undang nomor 20 tahun 2003 tentang sistem pendidikan nasional memiliki fungsi dan tujuan mengembangkan kemampuan dan membentuk watak serta peradaban bangsa yang bermartabat, untuk berkembangnya potensi peserta didik agar menjadi manusia yang beriman dan bertaqwa kepada Tuhan Yang Maha Esa, berakhlak mulia, sehat, berilmu, cakap, kreatif, mandiri, dan menjadi warga Negara yang demokratis serta bertanggungjawab. Untuk mencapai tujuan tersebut tidak terlepas dari peran serta orang tua atau keluarga. Keluarga merupakan bagian dari struktur sosial setiap masyarakat adalah salah satu unsur sosial yang paling awal mendapat dampak dari setiap perubahan sosial budaya. Pendidikan secara umumbertujuan untuk mengembangkan sumber daya manusia yang utuh dan handal, tetapi sering kali sangat idealitis dan tanpa arah sehingga kurang relevan dengan kebutuhan di lapangan. Pendidikan nasional berfungsi mengembangkan dan membentuk watak serta peradaban bangsa yang bermartabat dalam mencerdaskan kehidupan bangsa. Sedangkan tujuan pendidikan nasional untuk mengembangkan potensi peserta didik agar menjadi manusia yang berilmu, bertaqwa kepada Tuhan Yang Maha Esa, berakhlak mulia, sehat, berilmu, cakap, kreatif, mandiri, dan menjadi warga Negara yang demokratis serta bertanggungjawab. Oleh karena itu diperlukan manusia yang tangguh, handal, cerdas, berwatak kompetitif. Dengan demikian dibutuhkan suatu pembelajaran yang kreatif untuk menghasilkan manusia yang kreatif, memiliki ketrampilan, dan berkarakter.

Implementasi pendidikan karakter, diantaranya Penerapan pendidikan karakter pada pelaksanaan pembelajaran dilaksanakan dengan menggunakan strategi pendekatan kontekstual. Pengembangan budaya sekolah dan pusat kegiatan belajar dilakukan melalui kegiatan pengembangan diri, yaitu kegiatan rutin, kegiatan spontan, keteladanan, dan, pengkondisian. Menggiatkan kegiatan cokurikuler dan ekstra kurikuler yang merupakan aktifitas di luar kegiatan pembelajaran. Mengintensifkan kegiatan positif di lingkungan keluarga dan masyarakat, disamping juga di lingkungan sekolah.
\end{abstract}

Kata kunci: Pendidikan karakter, Mentalitas disiplin. 


\begin{abstract}
Education is a process of humanizing humans, namely a process that is able to realize a complete human being, raise awareness to recognize, understand, and understand the reality of life around him. According to Law Number 20 of 2003 concerning the National Education System, the function and purpose of developing capabilities and shaping the character and civilization of a dignified nation is to develop the potential of students to become human beings who believe and are devoted to God Almighty, have noble character, are healthy, and have good morals. knowledgeable, capable, creative, independent, and become a democratic and responsible citizen. To achieve this goal cannot be separated from the participation of parents or family. The family is part of the social structure of every society and is one of the earliest social elements to be impacted by any socio-cultural change. Education in general aims to develop human resources that are intact and reliable, but are often very idealistic and without direction so that they are less relevant to the needs in the field. National education functions to develop and shape the character and civilization of a dignified nation in the intellectual life of the nation. Meanwhile, the purpose of national education is to develop the potential of students to become human beings who are knowledgeable, devoted to God Almighty, have noble character, are healthy, knowledgeable, capable, creative, independent, and become democratic and responsible citizens. Therefore we need a man who is tough, reliable, intelligent, and has a competitive character. Thus, a creative learning is needed to produce creative, skilled, and characterized human beings.

Implementation of character education, including; The application of character education in the implementation of learning is carried out using a contextual approach strategy. Development of school culture and the center of learning activities is carried out through self-development activities, namely routine activities, spontaneous activities, exemplary, and conditioning. Enabling co-curricular and extra-curricular activities which are activities outside of learning activities. Intensifying positive activities in the family and community environment, as well as in the school environment.
\end{abstract}

Keywords: Character education, Discipline mentality.

\title{
I. PENDAHULUAN
}

Pembangunan kualitas pendidikan di Indonesia harus dilakukan secara bersamasama tidak hanya bagi kaum pemerintah dan para pendidik tetapi juga perlu melibatkan masyarakat, karena masyarakat memiliki peran penting untuk tercapainya suatu tujuan pendidikan yang berkualitas. Namun kenyataannya masyarakat menyerahkan sepenuhnya pendidikan siswa atau peserta didik hanya kepada para guru. Hal tersebut disebabkan oleh karena kurangnya pemahaman masyarakat terhadap pentingnya peran masyarakat dalam dunia pendidikan.

Masalah pendidikan sebagai proses pemanusiaan manusia membutuhkan sinergi antar komponen dan membutuhkan kesepahaman visi seluruh stake holder yang terlibat. Komponen pendidikan yang meliputi raw material (input siswa), tools (alatalat dan sarana prasarana), serta process (metode pembelajaran) adalah sebuah sistem yang akan menentukan kualitas out put (lulusan), sedangkan stake holder yang terdiri atas siswa, guru, kepala sekolah, wali murid, dinas terkait dan pemerintah daerah harus se-visi dan 
sinergi sehingga memperlancar dan mempermudah pencapaian tujuan baik tujuan akademis maupun pembentukan moral.

Kualitas pendidikan di Indonesia saat ini dinilai banyak pihak belum berkualitas, sebagai indikatornya adalah kualitas Human Development Index (Indeks Kualitas Manusia) berada di bawah negara-negara Asia Tenggara lainnya seperti Singgapura, Thailand, bahkan Vietnam. Ada beberapa faktor penyebab rendahnya kualitas pendidikan di tanah air antara lain: proses pembelajaran belum memperoleh perhatian optimal, masih ada para pendidik tidak memahami fungsi dan tujuan dari pendidikan. Guru lebih banyak bekerja sendirian, forum MGMP (Musyawarah Guru Mata Pelajaran) belum berfungsi optimal. Dengan tidak diketahuinya fungsi dan tujuan dari pendidikan tersebut oleh pendidik maka suatu pendidikan akan tidak terarah atau tidak mencapai suatu tujuan pendidikan.

Eksistensi generasi muda di Indonesia saat ini berada di era reformasi. Era reformasi ditandai dengan pelaksanaan hak asasi manusia secara utuh, dalam arti semua hak manusia dihargai dan dijunjung tinggi dengan memperhatikan hak orang lain. Namun hal ini disalah-artikan dalam pelaksanaannya. Hak-hak seseorang diminta untuk dihargai dengan sebebas-bebasnya tanpa memperhatikan hak-hak orang lain serta norma dan aturan yang berlaku. Akibatnya, banyak terjadi masalah-masalah sosial di masyarakat. Sebagai contoh, adalah adanya tindak kekerasan yang terjadi di mana-mana, tawuran antar pelajar, kurangnya rasa hormat serta sopan santun kepada orang yang lebih tua dan lain sebagainya.

Masalah-masalah sosial yang terjadi di masyarakat juga memberi imbas kepada kehidupan di sekolah, tidak hanya di sekolah tingkat atas, bahkan di sekolah dasar pun kerap terjadi masalah-masalah sosial tersebut. Adapun masalah-masalah tersebut meliputi pelanggaran-pelanggaran terhadap norma-norma yang berlaku di masyarakat. Masalah-masalah yang sering dijumpai adalah adanya siswa yang kurang hormat kepada bapak/ibu guru, kekerasan kepada siswa lainnya (bulying) dan lain sebagainya. Identifikasi masalah-masalah sosial di sekolah mengarah kepada adanya kekurangdisiplinan siswa. Ditengarai penyebab-penyebab adanya kekurang-disiplinan siswa adalah kurangnya kepedulian pihak-pihjak di sekitar siswa. Penyebab lainnya adalah mudahnya siswa mendapatkan "informasi" tanpa adanya penyaringan terlebih dahulu. Disinilah diperlukan adanya suatu pendidikan karakter bagi pengembangan mentalitas siswa

Pendidikan karakter merupakan gerakan nasional untuk menciptakan sekolah yang membina generasi muda yang beretika, bertanggung jawab dan perduli melalui pemodelan dan mengajarkan karakter baik, dengan penekanan pada nilai universal yang disepakati bersama. Ini adalah suatu usaha yang disengaja dan proaktif baik dari sekolah, daerah dan juga negara untuk menanamkan siswanya pada nilai etika utama, seperti menghargai diri sendiri dan orang lain, bertanggung jawab, integritas dan disiplin diri. Ini bukanlah suatu "perbaikan cepat" atau "obat kilat untuk semua", namun menyediakan solusi jangka panjang pada moral, etika, dan isu akademis yang menjadi keprihatinan yang berkembang di masyarakat dan keselamatan di sekolahsekolah. Berdasarkan uraian tersebut di atas, menarik minat penulis untuk menganalisis perkembangan mentalitas melalui pendidikan karakter, dimana diharapkan mampu membentuk nilai kedisiplinan di kalangan generasi muda. 


\section{PEMBAHASAN}

\subsection{Definisi Pendidikan Karakter}

Istilah pendidikan (education) secara etimologis berasal dari bahasa Latin yakni educare dan educere yang berarti melatih atau menjinakkan, menyuburkan. Jadi pedidikan merupakan sebuah proses yang membantu menumbuhkan, mengembangkan dan mendewasakan. Pendidikan merupakan suatu keharusan bagi manuisia, karena selain pendidikan sebagai gejala, juga sebagai upaya memanusiakan manusia. Menurut UU No. 20 Tahun 2003 tentang Sistem Pendidikan Nasional, pendidikan adalah usaha sadar dan terencana untuk mewujudkan suasana belajar dan proses pembelajaran agar peserta didik secara aktif mengembangkan potensi dirinya untuk memiliki kekuatan spiritual keagamaan, pengendalian dirinya, keperibadian, kecerdasan, akhlak mulia, serta keterampilan yang diperlukan dirinya, masyarakat bangsa dan negara.

Senada dengan uraian tersebut diatas, Djamarah (2005:22), menjelaskan bahwa pendidikan adalah suatu usaha sadar yang bertujuan untuk mengembangkan kualitas manusia. Sebagai suatu kegiatan yang sadar akan tujuan, maka dalam pelaksanaannya berada dalam suatu proses yang berkesinambungan dalam setiap jenis dan jenjang pendidikan. Secara kontekstual, pendidikan tidak hanya mencakup pada lembaga formal (sekolah) saja dan terikat oleh jenjang serta batasan waktu. Pendidikan berlangsung seumur hidup dan keluarga serta lingkungan masyarakat juga merupakan sebuah sistem pendidikan yang bertanggung jawab bagi pembentukan karakter seseorang. Kamus Besar Bahasa Indonesia (Depdikbud, 1990:204) menambahkan bahwa, istilah pendidikan merupakan proses pengubahan sikap dan tata laku seseorang atau kelompok orang, dalam usaha mendewasakan manusia melalui upaya-upaya pengajaran dan latihan, terkait proses, perbuatan ataupun cara mendidik.

Secara umum, istilah karakter sering diasosiasikan dengan apa yang disebut teemperamen. Selain itu karakter dilihat dari sudut pandang behavioral yang menekankan unsur somatopsikis yang dimiliki manusia sejak lahir. Dalam hal ini istilah karakter dianggap sama dengan kepribadian. Sedangkan kepribadian dianggap sebagai ciri, karakteristik, gaya atau sifat khas dari seseorang yang bersumber dari bentukanbentukan yang diterima dari lingkungan, misalnya keluarga pada masa kecil dan juga bawaan seseorang sejak lahir. Istilah karakter sesungguhnya menimbulkan ambiguitas (makna ganda). Kata character berasal dari bahasa Yunani charassein, yang berarti to engrave (melukis, menggambar), seperti orang yang melukis kertas, memahat batu atau metal. Berakar dari pengertian yang seperti itu, character kemudian diartikan sebagai tanda atau ciri yang khusus dan karenanya melahirkan sutu pandangan bahwa karakter adalah pola perilaku yang bersifat individual, keadaan moral seseorang. Setelah melewati tahap anak-anak, seseorang memiliki karakter, cara yang dapat diramalkan bahwa karakter seseorang berkaitan dengan perilaku yang ada di sekitar dirinya (Ryan dan Karen E. Bohlin, 1999:5).

Tentang ambiguitas terminologi "karakter" ini, Mounier, mengajukan dua cara interpretasi. Ia melihat karakter sebagai dua hal, yaitu pertama, sebagai sekumpulan kondisi yang telah diberikan begitu saja atau telah ada begitu saja, yang lebih kurang dipaksakan dalam diri kita. Karakter yang demikian ini dianggap sebagai sesuatu yang talah ada sejak lahir (given). Kedua, karakter juga bisa dipahami sebagai tingkat kekuatan melalui sejauh mana seseorang individu mampu menguasai kondisi tersebut. Karakter yang demikian ini disebutnya sebagai sebuah proses yang dikehendaki/willed (Koesoma, 2007:90). 
Aristoteles mendefiniskan karakter yang baik sebagai tingkah laku yang benar dalam hubungannya dengan orang lain dan juga dengan diri sendiri. Di pihak lain, karakter dalam pandangan filosof kontemporer seperti Michael Novak, adalah campuran atau perpaduan dari semua kebaikan yang berasal dari tradisi keagamaan, cerita dan pendapat orang bijak, yang sampai kepada kita melalui sejarah. Menurut Novak, tak seorang pun yang memiliki semua kebajikan itu, karena setiap orang memiliki kelemahan-kelemahan. Seseorang dengan karakter terpuji dapat dibedakan dari yang lainnya (Lickona, 1991:50).

Menurut Ahmad Amin (1995: 62) bahwa kehendak (niat) merupakan awal terjadinya akhlak (karakter) pada diri seseorang, jika kehendak itu diwujudkan dalam bentuk pembiasaan sikap dan perilaku. Dari konsep karakter ini muncul konsep pendidikan karakter (character education). Dari uraian di atas maka dapat disimpulkan bahwa pendidikan karakter adalah sebuah proses menumbuhkan, mengembangkan dan mendewasakan kepribadian seseorang.

\subsection{Fungsi, Tujuan Dan Nilai-nilai Dasar Pendidikan Karakter}

Tujuan pendidikan karakter adalah mendorong lahirnya anak-anak yang baik (Wina, 2008:29). Begitu tumbuh dalam karakter yang baik, anak-anak akan tumbuh dengan kapasitas dan komitmennya untuk melakukan berbagai hal yang terbaik dan melakukan segalanya dengan benar dan cenderung memiliki tujuan hidup. Meletakkan tujuan pendidikan karakter dalam rangka tantangan diluar kinerja pendidikan, seperti situasi kemorosotan moral dalam masyarakat yang melahirkan adanya kultur kematian sebagai penanda abad, memang bukan merupakan landasan yang kokoh bagi pendidikan karakter itu sendiri. Sebab dengan demikian, pendidikan karakter memperhambakan demi tujuan korektif, kuratif situasi masyarakat. Sekolah bukanlah lembaga demi reproduksi nilai-nilai sosial atau demi kepentingan korektif bagi masyarakat diluar dirinya, melainkan juga mesti memiliki dasar internal yang menjadi ciri bagi lembaga pendidikan itu sendiri.

Manusia secara natural memang memiliki potensi di dalam dirinya untuk tumbuh dan berkembang mengatasi keterbatasan dirinya dan keterbatasan budayanya. Di lain pihak manusia juga tidak dapat mengabaikan lingkungan sekitar dirinya. Tujuan pendidikan karakter mestinya diletakkan dalam kerangka gerak dinamis dialektis, berupa tanggapan individu atas implus natural (fisik dan psikis), sosial, kultural yang melingkupinya, untuk dapat menempa diri menjadi sempurna sehingga potensi-potensi yang ada dalam dirinya berkembang secara penuh yang membuatnya semakin menjadi manusiawi. Semakin menjadi manusiawi, berarti ia juga semakin menjadi mahluk yang mampu berelasi secara sehat dengan lingkungan di luar dirinya tanpa kehilangan otonomi dan kebebasannya sehingga dia menjadi manusia yang bertanggung jawab. Untuk ini, ia perlu memahami dan menghayati nilai-nilai yang relevan bagi pertumbuhan dan penghargaan harkat dan martabat manusia yang tercermin dalam usaha dirinya untuk menjadi sempurna melalui kehadiran orang lain dalam ruang dan waktu yang menjadi ciri drama singularitas historis tiap individu.

Dengan menempatkan pendidikan karakter dalam kerangka dinamika dan dialektika proses pembentukan individu, para insan pendidik diharapkan semakin dapat menyadari pentingnya pendidikan karakter sebagai sarana pembentuk pedoman perilaku, pengayaan nilai individu dengan cara menyediakan ruang bagi figur keteladanan bagi anak didik dan menciptakan sebuah lingkungan yang kondusif bagi proses pertumbuhan berupa, kenyamanan, keamanan yang membantu suasana pengembagan diri satu sama 
lain dalam keseluruhan dimensinya (teknis, intelektual, psikologis, moral, sosial, estetis dan religius).

Menurut Badan Penelitian dan Pengembangan (Balitbang), Adapun fungsi dan tujuan pendidikan karakter antara lain; 1) Pengembangan: pengembangan potensi siswa untuk menjadi pribadi berperilaku baik; ini bagi siswa yang telah memiliki sikap dan perilaku yang mencerminkan budaya dan karakter bangsa; 2) Perbaikan: memperkuat kiprah pendidikan nasional untuk bertanggung jawab dalam pengembangan potensi siswa yang lebih bermartabat; dan 3) Penyaring: untuk menyaring budaya bangsa sendiri dan budaya bangsa lain yang tidak sesuai dengan nilai-nilai budaya dan karakter bangsa yang bermartabat. Sedangkan tujuan pendidikan karakter adalah; 1) Mengembangkan potensi kalbu/nurani/afektif siswa sebagai manusia dan warga negara yang memiliki nilai-nilai budaya dan karakter bangsa; 2) Mengembangkan kebiasaan dan perilaku siswa yang terpuji dan sejalan dengan nilainilai universal dan tradisi budaya bangsa yang religius; 3) Menanamkan jiwa kepemimpinan dan tanggung jawab siswa sebagai generasi penerus bangsa; 4) Mengembangkan kemampuan siswa menjadi manusia yang mandiri, kreatif, berwawasan kebangsaan, dan 5) Mengembangkan lingkungan kehidupan sekolah sebagai lingkungan belajar yang aman, jujur, penuh kreativitas dan persahabatan, serta dengan rasa Kebangsaan yang tinggi dan penuh kekuatan atau dignity (Balitbang, 2010:7).

Menentukan nilai-nilai yang relevan bagi pendidikan karakter tidak dapat dilepaskan dari situasi dan konteks historis masyarakat tempat pendidikan karakter itu akan diterapkan. Sebab, nilai-nilai tertentu mungkin pada masa tertentu lebih relevan dan dalam situasi lain, nilai lain akan lebih cocok. Oleh karena itu, kriteria penentuan nilai-nilai ini sangat dinamis dalam arti, aplikasi praktisnya di dalam masyarakat yang akan mengalami perubahan terus menerus, sedangkan jiwa dari nilai-nilai itu tetap sama. Nilai-nilai pendidikan karakter perlu dikembangkan di sekolah. Nilai ini berlaku universal, karena dapat digunakan oleh seluruh siswa di Indonesia tanpa adanya diskriminasi terhadap pihak-pihak tertentu. Nilai-nilai ini bersumber dari agama, Pancasila, budaya dan tujuan pendidikan nasional.

Nilai-nilai yang ditanamkan dan dikembangkan pada sekolah-sekolah di Indonesia beserta deskripsinya adalah sebagai berikut:

1. Religius, adalah sikap dan perilaku patuh dalam melaksanakan ajaran agama yang dianutnya, toleran terhadap pelaksanaan ibadah agama lain, dan hidup rukun dengan pemeluk agama lain.

2. Jujur, adalah perilaku yang didasarkan pada upaya menjadikan dirinya sebagai orang yang selalu dapat dipercaya dalam perkataan, tindakan dan pekerjaan.

3. Toleransi, adalah sikap dan tindakan yang menghargai perbedaan agama, suku, etnis, pendapat, sikap dan tindakan orang lain yang berbeda dari dirinya.

4. Disiplin, adalah tindakan yang menunjukkan perilaku tertib dan patuh pada berbagai ketentuan dan peraturan.

5. Kerja Keras, adalah perilaku yang menunjukkan upaya sungguh-sungguh dalam mengatasi berbagai hambatan belajar dan tugas, serta menyelesaikan tugas dengan sebaik-baiknya.

6. Kreatif, adalah berpikir dan melakukan sesuatu untuk menghasilkan cara atau hasil baru dari sesuatu yang telah dimiliki.

7. Mandiri, adalah sikap dan perilaku yang tidak mudah tergantung pada orang lain dalam menyelesaikan tugas-tugas. 
8. Demokratis, adalah cara berfikir, bersikap dan bertindak yang menilai sama hak dan kewajiban dirinya dan orang lain.

9. Rasa Ingin Tahu, adalah sikap dan tindakan yang selalu berupaya untuk mengetahui lebih mendalam dan meluas dari sesuatu yang dipelajarinya, dilihat dan didengar.

10. Semangat Kebangsaan, adalah cara berpikir, bertindak dan berwawasan yang menempatkan kepentingan bangsa dan negara di atas kepentingan diri dan kelompoknya.

11. Cinta Tanah Air, adalah cara berfikir, bersikap, dan berbuat yang menunjukkan kesetiaan, kepedulian, dan penghargaan yang tinggi terhadap bahasa, lingkungan fisik, sosial, budaya, ekonomi, dan politik bangsa.

12. Menghargai Prestasi, adalah sikap dan tindakan yang mendorong dirinya untuk menghasilkan sesuatu yang berguna bagi masyarakat dan mengakui, serta menghormati keberhasilan orang lain.

13. Bersahabat/Komuniktif, adalah tindakan yang memperlihatkan rasa senang berbicara, bergaul dan bekerja sama dengan orang lain.

14. Cinta Damai, adalah sikap, perkataan dan tindakan yang menyebabkan orang lain merasa senang dan aman atas kehadiran dirinya.

15. Gemar Membaca, adalah kebiasaan menyediakan waktu untuk membaca berbagai bacaan yang memberikan kebajikan bagi dirinya.

16. Peduli Lingkungan, adalah sikap dan tindakan yang selalu berupaya mencegah kerusakan pada lingkungan alam di sekitarnya dan mengembangkan upayaupaya untuk memperbaiki kerusakan alam yang sudah terjadi.

17. Peduli Sosial, adalah sikap dan tindakan yang selalu ingin memberi bantuan pada orang lain dan masyarakat yang membutuhkan.

18. Tanggung-jawab, adalah sikap dan perilaku seseorang untuk melaksanakan tugas dan kewajibannya, yang seharusnya dia lakukan, terhadap diri sendiri, masyarakat, lingkungan (alam, sosial dan budaya), negara dan Tuhan Yang Maha Esa (Balitbang, 2010:8).

\subsection{Implementasi Pendidikan Karakter}

Penerapan pendidikan karakter di lingkungan pendidikan dilakukan pada ranah pembelajaran (kegiatan pembelajaran), pengembangan budaya sekolah dan pusat kegiatan belajar, kegiatan ko-kurikuler dan atau kegiatan ekstrakurikuler dan kegiatan keseharian di rumah serta di masyarakat. Adapun penjelasan masing-masing ranah tersebut adalah sebagai berikut :

\section{Kegiatan pembelajaran}

Penerapan pendidikan karakter pada pelaksanaan pembelajaran dilaksanakan dengan menggunakan strrategi yang tepat. Strategi yang tepat adalah strategi yang menggunakan pendekatan kontekstual. Alasan penggunaan strategi kontekstual adalah bahwa strategi tersebut dapat mengajak siswa menghubungkan atau mengaitkan materi yang dipelajari dengan dunia nyata. Dengan dapat mengajak menghubungkan materi yang dipelajari dengan dunia nyata, berati siswa diharapkan dapat mencari hubungan antara pengetahuan yang dimilikinya dengan penerapan pengetahuan tersebut dalam kehidupan sehari-hari. Dengan pendekatan itu, siswa lebih memiliki hasil yang komprehensif tidak hanya pada tataran kognitif (olah pikir), tetapi pada tataran afektif (olah hati, rasa, dan karsa), serta psikomotor (olah raga) (Balitbang, 2011:8). 
Adapun beberapa strategi pembelajaran kontekstual antara lain; a) pembelajaran berbasis masalah, b) pembelajaran kooperatif, c) pembelajaran berbasis proyek, d) pembelajaran pelayanan dan e) pembelajaran berbasis kerja. Balitbang (2010:9) menjelaskan bahwa kelima strategi tersebut dapat memberikan nurturant effect pengembangan karakter siswa, seperti: karakter cerdas, berpikir terbuka, tanggung jawab, rasa ingin tahu.

\section{Pengembangan Budaya Sekolah dan Pusat Kegiatan Belajar}

Pengembangan budaya sekolah dan pusat kegiatan belajar dilakukan melalui kegiatan pengembangan diri, yaitu kegiatan rutin, kegiatan spontan, keteladanan, dan pengkondisian. Adapun hal-hal tersebut adalah sebagai berikut.

a. Kegiatan rutin

Kegiatan rutin merupakan kegiatan yang kontinyu dilakukan setiap saat, dilakukan siswa secara terus menerus dan konsisten setiap saat. Beberapa contoh kegiatan rutin antara lain kegiatan upacara hari Senin, upacara besar kenegaraan, pemeriksaan kebersihan badan, piket kelas, sembahyang purnama-tilem, berdoa sebelum pelajaran dimulai dan diakhiri serta mengucapkan salam apabila bertemu guru, tenaga pendidik dan teman.

b. Kegiatan spontan

Kegiatan spontan dapat juga disebut kegiatan insidental. Kegiatan ini dilakukan secara spontan tanpa perencanaan terlebih dahulu. Contoh kegiatan ini adalah mengumpulkan sumbangan ketika ada teman yang terkena musibah atau sumbangan untuk masyarakat ketika terjadi bencana.

c. Keteladanan

Keteladanan merupakan sikap "menjadi contoh". Sikap menjadi contoh merupakan perilaku dan sikap guru dan tenaga kependidikan dan siswa dalam memberikan contoh melalui tindakan-tindakan yang baik sehingga diharapkan menjadi panutan bagi siswa lain. Contoh kegiatan ini misalnya guru menjadi contoh pribadi yang bersih, rapi, ramah dan supel.

d. Pengkondisian

Pengkondisian berkaitan dengan upaya sekolah untuk menata lingkungan fisik maupun nonfisik demi terciptanya suasana mendukung terlaksananya pendidikan karakter. Kegiatan menata lingkungan fisik misalnya adalah mengkondisikan toilet yang bersih, tempat sampah, halaman yang hijau dengan pepohonan, poster katakata bijak yang dipajang di lorong sekolah dan di dalam kelas. Sedangkan pengkondisian lingkungan nonfisik misalnya mengelola konflik antar guru supaya tidak menjurus kepada perpecahan atau bahkan menghilangkan konflik tersebut.

\section{Kegiatan ko-kurikuler dan atau kegiatan ekstrakurikuler}

Kegiatan ko dan ekstra kurikuler merupakan kegiatan-kegiatan di luar kegiatan pembelajaran. Meskipun di luar kegiatan pembelajaran, guru dapat juga mengintegrasikannya dalam pembelajaran. Kegiatan-kegiatan ini sebenarnya sudah mendukung pelaksanaan pendidikan karakter. Namun demikian tetap diperlukan perencanaan, pelaksanaan dan evaluasi yang baik atau merevitalisasi kegiatan-kegiatan ko dan ekstra kurikuler tersebut agar dapat melaksanakan pendidikan karakter kepada siswa. 


\section{Kegiatan keseharian di rumah dan di masyarakat}

Kegiatan ini merupakan kegiatan penunjang pendidikan karakter yang ada di sekolah. Rumah (keluarga) dan masyarakat merupakan partner penting suksesnya pelaksanaan pendidikan karakter di sekolah. Pelaksanaan pendidikan karakter sebaik apapun, jika tidak didukung oleh lingkungan keluarga dan masyarakat akan sia-sia. Dalam kegiatan ini, sekolah dapat mengupayakan terciptanya keselarasan antara karakter yang dikembangkan di sekolah dengan pembiasaan di rumah dan masyarakat (Balitbang, 2010:8).

\section{SIMPULAN}

Pendidikan karakter adalah sebuah proses menumbuhkan, mengembangkan dan mendewasakan kepribadian seseorang. Sedangkan tujuan pendidikan karakter adalah mendorong lahirnya anak-anak yang baik. Begitu tumbuh dalam karakter yang baik, anak-anak akan tumbuh dengan kapasitas dan komitmennya untuk melakukan berbagai hal yang terbaik dan melakukan segalanya dengan benar, dan cenderung memiliki tujuan hidup.

Adapun fungsi pendidikan karakter; 1) Pengembangan potensi siswa untuk menjadi pribadi berperilaku baik; 2) Memperkuat kiprah pendidikan nasional untuk bertanggung jawab dalam pengembangan potensi siswa yang lebih bermartabat; dan 3) Menyaring budaya bangsa sendiri dan budaya bangsa lain yang tidak sesuai dengan nilai budaya dan karakter bangsa yang bermartabat. Adapun nilai-nilai pendidikan karakter yaitu, religius, jujur, toleransi, disiplin, kerja keras, kreatif, mandiri, demokratis, rasa ingin tahu, semangat kebangsaan, cinta tanah air, menghargai prestasi, bersahabat atau komunikatif, cinta damai, gemar membaca, peduli lingkungan, peduli sosial, tanggung jawab.

\section{DAFTAR PUSTAKA}

Ahmad, Amin. 1995. Etika (Ilmu Akhlak). Terj. oleh Farid Ma'ruf. Jakarta: Bulan Bintang. Cet. VIII.

Balitbang Puskur. 2010. Pengembangan Pendidikan Budaya dan Karakter Bangsa: Pedoman Sekolah. Jakarta: Kemdiknas Balitbang Puskur.

Depdiknas, 2003, Undang-Undang No. 20 Tahun 2003, Sistem Pendidikan Nasional, www.depdiknas.go.id

Departemen Pendidikan dan Kebudayaan. 1990. Kamus Besar Bahasa Indonesia. Jakarta : Balai Pustaka.

Djamarah, Syaiful Bahri. 2005. Guru dan Anak Didik Dalam Interaksi Edukatif. Jakarta: Rineka Cipta.

Koesoma. 2007. Pendidikan Karakter pada Sekolah. Jakarta: Kencana.

Lickona, Thomas. 1991. Educating for Character: How Our School Can Teach Respect and Responsibility. New York: Bantam Books.

Ryan, Kevin dan Karen E. Bohlin. 1999. Building Character in Schools: Practical Ways to Bring Moral Instruction to Life. San Francisco: JOSSEY-BASS A Wiley Imprint.

Wina, Sanjaya. 2008. Teori dan Perkembangan anak. Jakarta: Gramedia Citra. 